\title{
Social distance between local residents and African-American expatriates in the context of Ghana's slavery-based heritage tourism
}

\author{
Aaron Yankholmes ${ }^{1}$ (b) I Dallen J. Timothy ${ }^{2}$
}

${ }^{1}$ Faculty of Management, Bournemouth University, Talbot Campus, Poole, BH12 5BB, UK

${ }^{2}$ Arizona State University, School of Community Resources and Development, Phoenix, AZ, USA

\section{Correspondence}

Aaron Yankholmes, Faculty of Management, Bournemouth University, Talbot Campus, Poole, BH12 5BB, UK.

Email: ayankholmes@bournemouth.ac.uk

\begin{abstract}
This paper explores the social distance between local residents and African-Americans who have settled in Ghana since the 1960s. Data generated from in-depth interviews suggest the AfricanAmerican expatriates felt their proximity to collective slave memory or particularly slavery heritage conferred on them certain rights to exclude local residents who are more susceptible to forgetting the past. By appropriating traces of the past, the African-American expatriates provide a range of tourism services, albeit to visitors they believed subscribed to socially constructed meanings elicited at slave sites. The study suggests explicit recognition of African-American expatriates in the levels of contestations that result from slavery-based heritage tourism.
\end{abstract}

KEYWORDS

African-American expatriates, Ghana, strangers, slavery-based heritage tourism, social distance,

\begin{abstract}
The strangerwill thus notbeconsidered here in the usual sense of the term, as the wandererwhocomestodayand goes tomorrow, but rather as the man who comes today and stays tomorrow... He is fixed within a certain spatial circle - or within a group whose boundaries are analogous to spatial boundaries - but his position within it is fundamentally affected by the fact that he does not belong in it initially and that he brings qualities into it that are not, and cannot be, indigenous to it. Georg Simmel (1971:143)
\end{abstract}

\section{I INTRODUCTION}

Diaspora African 're-migration' to presumed homelands in Africa involves far more than just the search for a personal past. It is also imbued with many symbolic and social meanings in which one's exercise of a natural right to 'return' is an act that a host and ancestral community may welcome or treat with a mixture of awe and suspicion. The inevitable result is a degree of psychological and emotional detachment from members of the host society, which entails assuming a new status and role. Simmel (1971) refers to this situation as entering 'strangerhood', which may result in social distance between residents and immigrants or visitors being reified and expanded through a host society's actions and behaviors (Gallois, Callan, \& Parslow, 1982; Karakayali, 2009; Nyaupane, Timothy, \& Poudel, 2015).

While this process is well recognized, few empirical studies have examined how certain groups of people enter or disentangle themselves from strangerhood (Levine, 1979). In particular, little is known about how diasporic Africans on a mystic quest to 'reconnect' with their ancestry segregate the natives and the significant factors accounting for that change in relationship. This study seeks to address this gap in empirical research by reporting on the social relationship between local residents of three communities in Ghana and the African-Americans who have established a long-term 'temporary' residence there. Specifically, the study explores the reasons for the 'return' and how the immigrants deploy their social proximity and distance in constructing a collective identity; their role in enabling the African-American 'root-seekers' to consume slave sites and how that role affects tourism; and their involvement in the promotion of tourism on the Slave Routes. 



\section{1 | Simmel's concept of stranger and its} applicability to African-American expatriates in Ghana

As previously noted, Simmel (1971) suggested that immigrants to a new society can become emotionally detached from that host society. This sense of 'strangerhood' may develop, at least in part, because of the host community's behavior towards and treatment of the strangers. The strangering process hinges on a distinct combination of two opposing factors, namely, closeness and remoteness, which Park (1924) and Bogardus (1933) refer to as social distance. Social distance, or social proximity, is created through degrees of understanding, interaction and intimacy in inter-group or inter-personal social relations (Park, 1924). It is a measure of how different one group sees itself, socio-culturally, racially, ethnically or religiously, from another group (Gallois et al., 1982; Nyaupane et al., 2015).

The synthesis of these contradictory factors (i.e. social nearness or distance) determines the formal position and status of the stranger within the host community. Thus, the stranger is near in that $s / h e$ interacts with several members of the host group but is also remote because the relationship is incidental or superficial rather than being based on community or kinship ties. However, a metamorphosis of the relationship may also occur in which the stranger may wish merely to be a resident without becoming assimilated into the host community (Skinner, 1963; Wood, 1934). Many representations of strangerhood are evident in the case of African-Americans who migrate to Ghana as residents in relation to their host communities.

There has been a large body of literature since the 1950s that focuses on the 'return' migration of members of the African diaspora, especially African-Americans, to Africa (e.g. Drachler, 1975; Dunbar, 1968; Gaines, 1999; Harris, 1982; Locksley, 1986; Schramm, 2004). This is perhaps not surprising because it has long been a commonly held but now discredited view that the motivation of Pan-Africanism (which partly encourages a return to Africa) is paradigmatically an AfricanAmerican concept (Akyeampong, 2000; DuBois, 1933; Isaacs, 1959; Moore, 1963; Shepperson, 1960, 1974; Stuckey, 1994; Tölölyan, 1996; Udom, 1962, 1971). Before the emergence of African diaspora ('roots') tourism in the 1980 s, there was already the concept of 'Africa interest', during which several prominent African-Americans 'returned' to their ostensible homelands, particularly Ghana, in search of their ancestral 'roots' and to spearhead socio-economic development across the African continent (Assensoh, 2010; Drake, 1966; Weisbord, 1973). However, tourism researchers find themselves in a quandary problematizing the 'return' either as a form of visiting friends and relatives tourism, pilgrimage, heritage tourism or all of the above (Asiedu, 2005; Duval, 2002; Ebron, 2000; Leite, 2005; Reed, 2006; Timothy, 1997; Timothy \& Teye, 2004). The reasons for this are manifold, but there are two important factors to take into consideration when attempting to understand 'return' visits to Africa by diasporic Africans First, the idea of the 'return' is anachronistic and misleading, to say the least. Diasporic Africans who themselves did not emigrate from Africa (and are not just recurrent tourists) cannot be described as returnees because they never domiciled there. Rather, they are descendants of those dispersed by the Transatlantic Slave Trade between the 1500s and the 1800s (Shepperson, 1966). Understood in this way, the quest for collective heritage extends far beyond a particular place being a 
homeland than any actual evidence of precise origins. It is therefore not surprising that the ways in which the 'returnees' participate in the life of their ancestral communities is carefully defined by the latter as befitting the role of the stranger.

Second, and closely related to the definitional problem, is the his- torical-political context within which the 'return' takes place. In the specific case of Ghana, the first wave of return migration, which occurred in the 1830s, was spurred by the emancipation and manu- mission of Afro-Brazilians in Bahia. The second wave involved trained

Afro-Caribbean professionals from the West Indies who were brought

in to assist British colonial expansion projects in what was then known as the Gold Coast. The African-American migration happened after the Gold Coast attained independence (as Ghana) from Britain in 1957. Under the aegis of Kwame Nkrumah's Pan-Africanist philoso- phy and a nonaligned foreign policy, many African-Americans moved to Ghana. That notwithstanding, a noteworthy distinction between the Afro-Brazilian migrants and their African-American counterparts was that the latter were mostly descendants of freed slaves (Essien, 2014). Moreover, unlike the Afro-Brazilian returnees who were given access to land and resettled by the host community, African-Ameri- can expatriates were not exactly welcomed with open arms by every- body (Boadi-Siaw, 2009). Rather, they were treated with suspicion and, in some cases, hostility, which resulted in a frosty relationship between them (Osei-Tutu, 2007; Zachary, 2001). Although Skinner (1982) draws attention to the dialectic contradictions between dia-

sporic people and their presumed homelands, in the case of diaspora Africans who have made the personal commitment to 'return', there is little recognition of the socio-cultural situatedness within which they find themselves in the ensuing conflict (Lake, 1995; Mwakikagile,

2005; Nti, 2014).

Ghana has been a subject of a number of African-American 'returnee' studies, but few have analyzed the extent of AfricanAmer- ican expatriates' involvement in the tourism industry except those dealing with the interpretation, presentation and conservation of the Cape Cost and Elmina castles (Austin, 2002; Bruner, 1996; Kreamer, 2004; Macgonagle, 2006; Mensah, 2015; Mowatt \& Chancellor, 2011; Osei-Tutu, 2004, 2007; Reed, 2004; Shackley, 2001). Unsurpris-

ingly, these studies show that African-American settlers are opposed

to the idea of the forts and castles serving a broader market. In partic- ular, they raise concerns over the commodification of slavery through this interpretation of the Transatlantic Slave Trade, which is not always readily acknowledged at the Cape Coast and Elmina castle museums. Indeed, Holsey (2008) even goes so far as to say that the entire museum exhibits at Cape Coast Castle and
Elmina Castle deliberately ignore that long ignominious history. Apart from the obvious discor- dant and romanticized historical interpretations of slavery and the Eurocentric historiographical narrative about it, Holsey notes that the slavery heritage experiences of visitors, particularly Africans of the diaspora, are subtly manipulated by the burgeoning tourism industry.

From the preceding scenario, it may seem strange and grossly inconsistent to associate the 'returnees' with the promotion of tourism along Ghana's Slave Routes and even more peculiar to describe the degree of their involvement in the interpretation and presentation of slave-related sites to African-American roots tourists whose needs they perceived as compatible with their own. 


\section{I METHOD}

This study adopted a qualitative approach using in-depth interviews to analyze the stories expressed by relatively small numbers of African-American expatriates in Ghana. This was considered the most appropriate method to 'gain access to the cultural categories and assumptions according to which one construes the world' rather than discovering 'how many, and what kinds of people share a certain characteristic' by mining the cultural terrain instead of surveying it (McCracken, 1988:17)

At the outset of the study, contact was made with some wellknown African-American expatriates who operated tourism-related businesses. A list of potential participants was developed based on their referrals, but inclusion depended on the participant's willingness to be interviewed. This approach provided a specific set of social circumstances in which to situate the study's findings. The participants were contacted by phone and asked if they would be willing to participate in a research project seeking to examine the touristification of slave sites through UNESCO's Slave Routes Project. All of those contacted indicated that the study topic was personally relevant and expressed enthusiasm in participating. However, this approach was prone to bias, including the possibility of oversampling participants with larger personal networks while excluding those with fewer. To address this bias, sampling focused on saturating the three targeted communities to capture informants with the full array of network sizes (Heckathorn, 1997). Ethical approval to undertake this study was sought and granted by the first author's institution.

The study participants are summarized in Table 1. A total of 12 participants had moved to Ghana for reasons of filial piety. Seven women and five men were interviewed with an average age in their early 40s.They were fairly well-educated, trained professionals engaged in both private and public sector jobs in the nation's capital, Accra, and in Cape Coast and Elmina. The majority had lived continuously in Ghana for at least 25 years and hailed from the American South or US cities with large African-American populations.
Most of the interviews took place in the participants' homes, although some were held at their workplaces. Interviews were conducted in June 2012 with one follow-up in August of the same year.

All were semi-structured, long interviews, which lasted from 1.5 to 2 hours. Participants were assured full anonymity and confidentiality, and each signed consent forms explaining the purpose and intended use of the data.

The interviews covered a wide range of topics including participants' background information, lived experiences and social relations in their ancestral/adopted communities and involvement in the tourism industry. The first topic was their personal and family history, past and current socio-economic status, motivation for moving to Ghana and sense of belonging and attachment to Ghana. The dialogue then covered a broad range of slavery heritage tourism issues, including performances and rituals practiced at slavery sites (particularly the Cape Coast and Elmina castles and the Assin Manso Slave River), roots tourism promotion, and the conservation and preservation of such places. At the end of the interviews, participants had an opportunity to ask questions or return to issues that arose earlier that they might have wanted to clarify or elaborate on further.

All interviews were transcribed verbatim. To ensure trustworthiness, all transcriptions were forwarded to each interviewee to review and verify whether their thoughts were accurately captured by the text (Lincoln \& Guba, 1985). In some cases, changes were made, and the lead researcher then listened to the digital recordings to identify any errors. The transcriptions were repeatedly re-read to achieve immersion and to become thoroughly familiar with the data. During the initial reading, however, key phrases, metaphors and patterns of meaning were noted. Qualitative data analysis software (e.g. N-VIVO) was considered, but to enable better and more imaginative data analysis, the coding criteria specified by Strauss and Corbin (1998) were followed. This approach provided a much broader picture of the results. Through each iteration, thematic similarities and meaning-based linkages were developed. Moreover, throughout the interpretation process, the themes were continuously challenged and modified by returning to the concentrated experiences described in each interview.

TABLE 1 List of participants

\begin{tabular}{|c|c|c|c|c|c|c|c|c|}
\hline Location & Pseudonym $^{\mathrm{a}}$ & Age & Sex & Education & Hometown/place of origin & Occupation & Years in Ghana & Year moved \\
\hline Accra & Serwa & 55 & $\mathrm{~F}$ & Degree & Dallas, TX & Teacher & 23 & 1989 \\
\hline Accra & Araba & 52 & $\mathrm{M}$ & Degree & Detroit, MI & Administrator & 20 & 1992 \\
\hline Accra & Adwoa & 62 & $\mathrm{~F}$ & Diploma & Los Angeles, CA & Retired administrator & 31 & 1981 \\
\hline Accra & & 53 & $\mathrm{~F}$ & Degree & Atlanta, GA & Registered nurse & 23 & 1989 \\
\hline Accra & Aba & 46 & $\mathrm{~F}$ & Diploma & Newark, NJ & Beautician & 20 & 1992 \\
\hline Accra & Ama & 75 & $\mathrm{~F}$ & Diploma & Cleveland, $\mathrm{OH}$ & Retired/business owner & 52 & 1960 \\
\hline Cape Coast & Kwame & 46 & $\mathrm{M}$ & Degree & Bronx, NY & Travel agent & 20 & 1992 \\
\hline Cape Coast & Kofi & 63 & $\mathrm{M}$ & Degree & Brookyln, NY & Runs private hotel business & 19 & 1993 \\
\hline Cape Coast & Kwesi & 50 & $\mathrm{M}$ & Diploma & Charleston, SC & Social worker & 20 & 1992 \\
\hline Cape Coast & Kukuwaa & 45 & $\mathrm{~F}$ & Degree & Brooklyn, NY & Software analyst & 20 & 1992 \\
\hline Elmina & Akosua & 68 & $\mathrm{~F}$ & Diploma & Bronx, NY & Runs family hotel business & 23 & 1989 \\
\hline Elmina & Kwamena & 63 & $\mathrm{M}$ & Diploma & Bronx, NY & Tour operator & 25 & 1987 \\
\hline
\end{tabular}

Note: 
${ }^{a}$ Pseudonyms are indigenous Ghanaian Akan names. In cases where study participants had assumed indigenous names, they were changed to ensure their anonymity. 


\section{I RESULTS AND DISCUSSION}

\section{1 | Silence of the return, collective identity} construction, strangerhood and the crisis of belonging

The expatriates recounted their family histories, which primarily highlighted race and identity relations in the United States. With only one exception, they made unprompted references to race and discrimination as factors in their decision to migrate to Africa. For these expatriates, experiencing racism and discrimination was the basis of their rejecting the label 'African-American'. They felt that the term 'African-American' and the discrimination they experienced because of their African roots bespoke white Americans' intentions. Thus, the return to their romanticized 'homeland' was an escape from racism psychologically and physically, as well as an opportunity to immortalize their ancestors in the articulation of collective slave memory. For example,

Kwame: I felt the spirits of my ancestors the first time I set foot on this land. The spirits of the innocent people who didn't commit any crime except that they were unfortunately at the wrong place at the wrong time... Ghana is my spiritual home. There is no doubt in my mind that this is where I belong. Surely a fie nie fie [In local Akan dialect meaning home is home].

Akosua: My subsequent visit to Ghana opened up an area that I was not familiar with in terms of the history of African people and our relationship to the castle dungeons. It had more to do with once you come to the recognition that Africa is in fact your home as an African person. An understanding that my association with America has very much to do with 500 years of slavery... um, and the fact that I was born in the America had a cultural tie, an ancestral tie to Africa. Once I realized that and saw that Ghana was not some remote place, people weren't living on trees and all that stuff, made me appreciate more the fact that I was in fact an African and that I did have some place.

Kwesi: I would say that moving to Africa is probably the most important undertaking for any African born in the United States. It's about slavery and indignity meted out on the enslaved Africans. It's about the millions who died in bondage and burden of displacement that all Africans born in America must carry until they return to the homeland to be spiritually cleansed. I feel this connection deep in my bones.

The 'return' narrative was an overt way of justifying collective identity construction. Without a doubt, Ghana was an important place in this process, as it evokes a sense of attachment and primordial belonging. More importantly, collective identity construction entailed building huge social networks that extended beyond local residents' conception of 'strangers'. However, the degree to which collective identity or, indeed, a sense of belonging is constructed involves critical collective slave memory dimensions that give strangerhood a spatiotemporal depth of meaning. It embraces not only the remembered past but also ancestral communities in which contemporary use of slave sites for tourism purposes is heavily contested (Yankholmes \& McKercher, 2015). 
For the expatriates, social proximity translates into a sense of belonging found within close-knit ancestral families. At several points during the interviews, each participant was asked how he or she related to ancestral family members without direct DNA testing. Bodily features were offered as proof of genetic connections. Anecdotal evi- dence suggests that perhaps the mere presence of local descendants of African 'slaves', although socially stigmatized and discriminated against by local residents in places such as Cape Coast and Elmina, cre- ated kinship identities and strengthened collective identity.

Kwamena: I returned to Ghana enthralled by the prospect of being free. You can only feel that among your people. In United States, you always have a heavy sense of foreboding hangs in the air walking on the street. I just came back to have a sense of self-consciousness, and by reconnecting my roots, you know what I mean. The feel- ing is right here. The affinity is here, and I have com- pleted the full circle by going through the door of return at the Cape Coast Castle. So, there is no doubt about who I am or what my status is compared to the White man who enslaved my ancestors.

Kwesi: In America, I'd be a nobody. Here people see you and instinctively trace your physical semblance to family, and that how you feel a sense belonging.

Kofi: $\quad$ For some of us, we know America is not utopia...to say that you have left that beautiful place to come to this place. Beauty can be measured in different forms... The beauty of me being respected as a human being is worth the beauty that I left in America. In that respect, I do the comparative analysis from a complex view about what is development. Is development about five lane highways and skyscrapers where people don't know their next- door neighbor and they don't speak to each other and there is a murder every thirty seconds and people don't feel safe with each other? Or is development when I go to a place and somebody greets me with a smile in the morning and young people still respect adult and younger persons would ask older persons whether they can carry their bag for them? I think that is more development because that is development of human character. How- ever, when someone is hated for the color of their skin or we find that because they are different, then that's under-development of character... so we in America may be physically developed, but in terms of the soul and character, America is an undeveloped country.

At the same time, they experienced socially distanced relationships with the resident population. Although a pervasive theme, there were some variations due to the distinct socio-historical context of the study locations and the nature of the relationships with local residents. Few participants could articulate the basis of their social distance from local residents and the resultant impact on their sense of collective identity and belonging. For example, Akosua claims that the reluctance of some local residents to discuss slavery openly and their vulnerability to forgetting the past (either unconsciously repressed or politically motivated) underlies the 'uncomfortably' cordial relationship. She says: 
They want to forget...indigenous Ghanaians are like that...they don't want to talk about the Slave Trade... we were doing a film, and part of it was to interview indigenous Ghanaians and get their take on the Transatlantic Slave Trade. What they think about it, what kind of impact it had on them and most of them excuse meto say, don't want to talk about it... 'We should forget it' ... they asked, 'why do you bring this stuff up?' ... I said because it is important, it is part of our history, it is the connection, it is the understanding, the deep understanding of who we are as African people and what our connection is...(hissed) 'we should forget about it, it is a shameful period' they retorted. Then, I went to another place where they had children. We were talking so they asked the children to leave... 'I said no, let the children stay because it's their history'. 'They said oh! They don't need to know'. Few people wanted to talk about it. The unfortunate thing is we get a bad 'rap' coming from the diaspora asking these questions.

She cited numerous instances in which locals failed to appreciate the heritage shared with African-Americans because they did not want to have a conversation about slavery. Otherwise, the relationship was cordial on the surface, albeit somewhat 'uncomfortable'. Aba concurs, saying:

It's mind-boggling that after more than four centuries [and] since the abolition of slavery, Ghanaians still can't openly have a conversation about slavery. Even with the increasing number of diasporans returning to the motherland. When I asked one elder at the chief's palace why local people don't go to slave sites to clear their heads like we do, he said 'You see, we prefer going forward to going back to history'.

Similarly, Ama linked this response to Ghanaians' feeling of guilt and its related emotion, cruelty, regarding their ancestors' connivance with European slave traders to sell their kith and kin, while Kofi ascribed it to local residents' ignorance about the historical dilemma and dynamics of what caused the African dispersion. On the other hand, Araba alludes to early repatriates who created social spheres of influences that destroyed mutual trust and respect. However, all of the expatriates refused to relocate back to the United States. They had decided - implicitly or explicitly - that their future lay in integration and, perchance, actual assimilation without much resistance. However, to sustain collective identity, they felt symbolically drawn to local descendants of African 'slaves' in the community to the point of providing them the reference point in recounting collective slave memories that they in turn bought into.

There are two possible reasons for this social distance between expatriates and local residents. As mentioned, our findings are consistent with anecdotal evidence that the presence of the local descen- dants of African 'slaves' in or near former slave communities fosters a sense of collective identity and kinship links. However, due mainly to the social stigma attached to slavery in some former Slave Trade locales, which has been perpetuated over time, affiliation with place 
and proximity to certain segments of the ancestral community accen- tuate social distance. The fact is that local descendants of African 'slaves' in communities such as Cape Coast and Elmina are alsolabeled

'strangers' (that is, a nonsubject of a clan because of the matrilineal system of inheritance practiced there) given their servile origins. Within this context, social disdain was derived from any such associations with them. The interesting feature about this situation is that in these two towns, the general perspective among the indigenes is that one's servile status leaves an indelible mark even if one has moved up the socioeconomic ladder.

The second reason relates to the fact that informants' forged collective identity with local residents is relatively unstable. Many members of the African-American expatriate community are yet to renounce their American citizenship. While the Ghanaian government is yet to resolve some of the problems that have beset the implemen- tation of the law granting people of African descent 'right of abode', the fact is that the expatriates change or switch identities regularly in different situations. For instance, besides being free to come and go on visas or stay indefinitely in Ghana upon successful application to the authorities, African-Americans wanting to invest in or establish businesses may identify as such to enjoy incentives offered by the gov- ernment such as land, customs duty exemptions on machinery and tax holidays. Given these scenarios, their engagement with local residents depends not on their ancestral ties or loyalties but on their passports and, to some extent, self-identity. So, it is not unimaginable to think that for many local residents, the idea of collective identity as a deriv- ative of slavery was not a matter of domicile; the African-American expatriates enjoy economic advantages and social mobility unavailable to the locals. But when quizzed about claims the informants have a half-hearted African-centric identity, Kwesi invokes other factors in determination of loyalty.

...There are born-and-bred Ghanaians who have citizenship of other countries but they won't give it up and yet their legacy is not like that of an African-American. And America owes us. So, it's not a matter of split allegiance for most part for America. There are returns from pensions, returns from retirement packages that benefit Ghana's economy and it comes in with also keeping that which allows us to be in a position to affect better development investment and change here. So I think Ghana should see that an asset not as a split loyalty. As much as a Ghanaian does not run away from most part his home because he doesn't love it but because he looking for greater access to resources.

Thus, it is conceivable that despite the African-American expatri- ates' affinity towards local residents, the latter frequently distance themselves. These observations, taken together, lend credence to Simmel's (1971) contention that some strangers are culturally less dis- tant from their host than others because social distance is empha- sized more than nearness. For this reason, expatriates are not perceived as individuals, but as persons of a certain 'type'. This sub- culture highlights what they do not share with some segments of the ancestral community, especially their slave origins and American citizenship. 


\subsection{Performing the past}

The same questions raised by the idea of collective identity present themselves in the case of performances at slavery-related sites. Obviously, social distance discourages the expats from physical participation in spaces wherein the remembered past transpired. However, social distance, while constraining, is not insurmountable. This is because the sense of the inhumane treatment of their progenitors during the slave era is continually nourished. This unashamed wallowing in the past feeds directly into the notion of returning, even though the participants had never been there. As such, they are not only able to venerate the dead but project themselves into their ancestralspaces, thereby setting the stage for contestations implicitly or explicitly with other social groups and stakeholders who lay claim, legitimately or not, to these spaces. This point is well illustrated by the ways in which the expats become involved vicariously at slavery sites.

These 'dark' heritage places are used to invoke strong connections to the past through the 'initiation' of African-American roots tourists.

The symbolic enactment or ritual performance is the means by which expatriates encourage their compatriot tourists to discover their roots, not only by emotionally engaging with the sites but also by reconnecting with their motherland. This process is practiced at the Cape Coast and Elmina castles. For study participants, these performances were more than symbolic activities. They were a visceral experience that only descendants of slaves can understand in a lifetime and that transcends the power of mere words to describe.

Akosua: The men go to the male dungeons retracing our ancestors' footsteps and the women go into the female dungeons with me retracing the footsteps of my ancestors. We do a dirge that takes us into the dungeons and once inside the dungeons, we have an opportunity to come together, pray and meditate, talk about what the experience means to us being here. People have the opportunity not to only vent but become reconnected...so that things they did not know anything about once in the dungeons it comes together for them. This is a group of women who for the most part, do not know each other. Because they come on a tour and just met each other, we come together in that room as African people....and that's a lot more important.

Participants discussed collective slave memory as a key resource in engendering a sense of entitlement to, or ownership of, slaverelated sites. Given that these places have multiple visitor experiences (Timothy \& Teye, 2004), the expatriates felt the invocation of slave memories would stimulate a rejection of what is presented by site managers to visitors, especially for those who feel a personal connection to the past. As such, there is a clear agenda for acceptance. Again, Akosua provides a typicalillustration:

We don'tallow Europeans to participate in our ceremonies because we strongly believe; we strongly know there is a connection between us as African people...that's alot more important. White people, if they want to go down there and do anything, that's their own business; we are there to glorify our ancestors; we are there to give thanks to God, to the Creator for having returned us safely home to the land of our ancestors. 
This performance effect was also very apparent at the Assin Manso Slave River. Here, the possibility of a deeply personal visitor experience exists given the cultural significance of the site. This is the place where captives from the hinterlands were bathed, sorted and transported to the fort and castles in Cape Coast, Elmina and Anomabu (Ward, 1966). Although the water flow in the Slave River is seasonal, with some visitors only being able to see a dry riverbed, its symbolic status compared to other slavery sites is not lost on the

African-American expatriates. At this place, they have the chance to invoke emotions and consciousness among the African-American 'root-seekers'. However, the enactments are not only meant to stim- ulate their emotions but most importantly to facilitate their journey to the 'source' where they would appreciate at a deeper level the events of the past to put the present and the future into

perspective.

Adwoa: When they have gone through this process, it is then that they can remember and mourn their forebears while confronting the loss of their own identity.

Serwaa: I remember one sister told me she found peace within her- self after encountering her ancestral spirits. And I know that true because I experienced the transformative powers of the Slave River myself. Oh yes, [in a soft voice] I have been in that state before; yes, those were definitely the voices of my ancestors welcoming me home.

Thus, the invocation of emotions plays a key role in bringing the past to life. This enables roots tourists to psychologically explore for themselves the source of their forebears and make collective slave memory more meaningful for their touring experience. The picture the respondents in this study give of their affectual and emotional experiences at slave sites buttresses that found by Carter (2015) in his analysis of a highly viewed YouTube video as well as the issues of emotion in slavery tourism noted by Alderman and Campbell (2008) and Modlin (2011).

The immigrants reported concerns about the extent to which res- ident Ghanaians are cognitively distanced from slavery-related sites. They felt local residents only expected slave sites to educate them about the whole gamut of pre- and postcolonial history, not to stimu- late their emotions. As Ama described it,

The unwillingness to openly have a conversation about slavery does match their lackadaisical attitude towards going to the slave dungeons and experiencing it for themselves.

They would always say, what point does it make?

This comment is consistent with her earlier reported view that Ghanaians shy away from the subject of slavery because their forbearers were involved in the enslavement of their fellow Africans. Anecdotal evidence and visitor records at the Cape Coast and Elmina castles, although limited, do not support the claim that local residents do not visit slave-related sites, but it is possible that because local Ghanaians are aware of the impassioned allure of slave sites among the diaspora, they may wish to avoid the performative nature of African-American remembrances which diverge from their experi- ences when they visit such places. In regard to the charge of African complicity in the Slave Trade, Daaku (1970) dealt with the subject in unparalleled detail, but it appears to have been largely overlooked. It 
is a charge deeply rooted in a set of misconceptions of continental Africans that is firmly etched in the conscience of African-Americans (Akurang-Parry, 2010; Gates, 2010; Wamba, 1999).

\subsection{Involvement in tourism promotion}

Previous empirical research shows that resident expatriate AfricanAmericans feel the presentation and conservation of the forts and castles do not meet their needs. Against this background, participants were questioned about their involvement in the promotion of tourism on the Slave Routes. There was abundant evidence from the interviews that establishes a link between the expatriates' status as strangers and their interest in the management, conservation and presentation of the places associated with their personal past. Participants rarely referred to dialogue with site managers except when it had to do with ritual performances at the sites and the staging of Black History Month, Juneteenth Day, Emancipation Day and the Pan-African Historical Theatre (PANAFEST) observances. Therefore, instead of working together with other stakeholders to produce a truly outstanding slavery heritage tourism product, they isolate themselves by creating and thus reinforcing the distinction between the 'official' and self-created images of the places of their filial heritage. According to Kwesi,

Since folks here want to forget about the Transatlantic Slave Trade, we have made a conscious effort to preserve our ancestors' painful memory. I invent my past as a grand fiction....

The result is lost opportunities to provide quality visitor experiences at slave sites. However, it would seem that this loss has benefited the expatriates. There was, in fact, some clear evidence of their role as gatekeepers providing an array of services. These ranged from helping with visa applications, tour guiding and ground handling to interring cremated remains of African-Americans who asked that their ashes be scattered in the land where their enslaved ancestors originated and the provision of accommodations. In regard to the latter, the two study participants operating tourism businesses commented that they provide lodging facilities for visitors regardless of race or ethnicity, although the majority of their clients were identified as African-Americans. Despite this, the émigrés involved in tourism were unaware of the effects their gatekeeping role had on the industry. They believed their clients were seeking slavery heritage experiences that incorporate visits to authentic slave sites complemented by opportunities to meet local descendants of African slaves and local descendants of African slaveholders. When reminded of the charge by some local residents of stirring unpleasant memories at slave sites, they reacted with mild puzzlement. This reaction was sometimes followed by a justification that local residents were more vulnerable to forgetting than remembering the past and that the gaze of white visitors was not value neutral.

Until these interviews, none of the study participants were consciously aware that the basis of being called strangers might be because of the heightened sense of place stimulated by their emotional proximity to certain segments of the community and to slave sites, and their perceived half-hearted commitment to forging 
collective identity. Consequently, they performed their gatekeeping role not only to evoke a sense of emotional engagement with slave sites such that African-American roots tourists felt their ancestors' emotional pain and suffering but also to diversify visitations to tradi- tionally remote slavery heritage attractions in the north of the country. Akosuanoted,

We do assist our brothers and sisters who want to reconnect their ancestry find that true connection. I don't care what they tell the Europeans at castle dungeons. What we do helps bring us together as people with African heritage; it makes our brothers and sister talk about the journey to the homeland in apositive sense.

These comments confirm expatriates' perceptions of the tourists' needs. It nevertheless begs the question of whether being a stranger is transitory, fictional or illusionary, and what the reasons for this sta- tus might be (Schuetz, 1944). The interviews themselves provide little direct evidence. However, the question asked in relation to partici- pants' views on the conservation of slavery-related sites provides some insight. This issue was probed with participants in terms of their lived experiences and those reported in the literature (e.g. Butler, Car- ter, \& Dwyer, 2008; Buzinde, 2007; Dann \& Seaton, 2001; Modlin, 2008; Montes \& Butler, 2008).

Most participants were positive about their 'return' experiences and emphasized the intrinsic values of slavery-related sites. In all of the interviews, the participants had powerful recollections of their ini- tial years following their return, long before slavery-based heritage tourism was fashionable. Akosua had photographs and memorabilia, and she took time to explain their significance and provenance. These included excavated soil and debris taken from dungeons at the Cape Coast Castle, photographs of the first Emancipation Day observances in 1998 during which the remains of Samuel Carson of New York and Crystal of Jamaica were interred at Assin Manso. This treasure trove of personal possessions served as a sign of her immersion not only in influential political circles but also in the local community. Tour- ists who stay at her facility have the opportunity to see her collection. The participants showed no signs of being influenced by social distance from local residents. The local residents' reference to their ser- vile origins and aversion to connecting with an emotionally charged past meant nothing to them. It was easy to discern that such attitudes were fueled by a sense of entitlement that seemed to radiate from the loss or appropriation of slave sites in the United States in a manner that excluded them from use (Alderman, 2010; Alderman, Butler, \& Hanna, 2016). Indeed, some argued that for the majority of expatriates, there was no gain in continuing to proclaim strong collective identities if slave sites were consciously and unconsciously appropriated by previous perpetrators and their descendants. They saw their actions as correcting what they perceived to be historical and social injustices perpetuated at slavery heritage sites in America (Eichstedt \& Small, 2002; Hanna, 2008; Potter, 2016; Small, 2013). This feeling of disin- heritance was somewhat reduced when they remember slavery in emotive ways and tell their 'return' experiences

to African-American

root-seekers. Informants felt that the authenticity of slave sites in Ghana allowed them to experience an emotional realism not otherwise available in America. 


\section{ICONCLUSION AND RECOMMENDATIONS}

Since the 1980s, there has been a rapid growth in African-Americans visiting the lands of their forebears in West Africa (Bruner, 1996; Goodrich, 1985; Timothy \& Teye, 2004). Long before that, however, there was a significant migration of African-Americans 'returning' to their homeland, particularly Ghana, on a more permanent basis as expatriate residents. Many diasporic 'returnees' in the latter part of the twentieth century were motivated by a desire to connectemotionally and psychologically with their motherland and to escape the historical and contemporary manifestations of racism in the United States. Returning to their primordial homeland was a way of reconciling their multi-generational identity crises spurred by their slaveryensconced family histories and the discrimination they experienced because of their African roots. It was both an act of personally, and sometimes spiritually, connecting with their enslaved ancestors who were forcefully torn from their birthplace generations earlier and also an escape from the injustices in America.

Building social networks with their continental African neighbors and entrenching themselves within Ghanaian society meant constructing their collective slave memory in the place where slavery started. Nevertheless, while the social proximity to their ostensible kindred brothers and sisters should have satisfied a sense of belonging for these expatriates, their experiences did not always match that expectation. Many of them experienced socially distanced relationships with the resident population that increased their 'strangerhood' in the one place that they thought they would be most welcome. Bruner (1996) noted that when African-American root-seekers visit Ghana, many are disappointed to learn that they are considered strangers - simply tourists - by the residents, while they expected to be welcomed with open arms as brothers and sisters from the diaspora. The expatriate returnees profiled in this study had a similar experience even though their intent was to live in Ghana rather than simply to visit.

At least some of the social distance between the expatriates and locals derived from the expatriates' excessive connection to slave heritage sites and overemphasis on slavery. Because slavery did not 'happen' to the local population but did to the immigrants, social distances have emerged, resulting in the immigrants being considered strangers in what they felt should be their primeval homeland. The locals are simply unable to relate to the identity crisis of the returnees and their need to accentuate the injustices of slavery. The slave heritage sites do not bear the emotional weight for local Ghanaians that they do for the expatriates, which troubles many of the immigrants. As a result, many returnees continue to stress the emotive elements of slave heritage and underscore the injustices of slavery, whichcontinues to isolate them from their continental African neighbors and thereby reinforce their strangerhood.

Many African-American immigrants are involved in Ghana's heritage tourism sector. When they host African-American root-seekers at slave sites, their interpretive narratives are geared toward eliciting the emotive responses that they themselves experience by living near these vessels of injustice. In this way, they also enhance the strangerhood of the tourists and their social distance from the resident 
population. With regard to white tourists, many of the expatriate set- tlers manipulate the social distance between the tourists and the her- itage they visit. Some settlers are opposed to the notion of the slave heritage experience being consumed by a non-black consumermarket.

Some participants even noted that they do not allow non-black tourists

to participate in certain heritage activities and ceremonies. Thus, just as some resident Ghanaians distance themselves from the expatriates, many expatriates heighten their strangerhood and extend the social distance that they themselves abhor in their relationship with resident Ghanaians. Ameri-

The social distance between local Ghanaians and Africancan immigrants risks compromising the long-term sustainability of slavery heritage tourism in Ghana. Because the expats feel disinherited and separated from the indigenous population altogether, any efforts at safeguarding collective slave memories should be devoid of ethnocentrism, racial prejudice and stigmatism.

Accordingly, inter-cultural dialogue and inter-cultural trust between local residents and the African-American immigrant community should be strengthened through education and culturally sensitive support services. However, it is unlikely that such initiatives will build the social bridges with local residents overnight, without a deeper analysis of the dialec- tic contradictions in the relationships between diasporic people and their ancestral homeland (Skinner, 1982; Timothy, 2008). Many respondents appreciated the hospitality of their ancestral communi- ties, and for some of them, the return experience acted as a source of bounded solidarity. The development, promotion and management

of slave sites by different highly autonomous government departments and agencies that are under-funded and under-resourced need to be re-examined, as do the complex multiple contestations to the ownership, use, commemoration, interpretation and representations of slavery-related sites. Sustainability in this context would mean encouraging reciprocal relationships in the management of slavery

heritage tourism.

Most of all, the Ghanaian authorities need to develop a strategy that protects and enhances the quality of the slavery heritage experi- ence delivered by the country's numerous slave-related sites. Adopting

a quality-oriented strategy requires refocusing the overall management and presentation of slave-related sites to current and potential users. One specific issue raised by this study is the extent to which Ghanaian destination managers accept that such places have intrinsic values beyond their use value as tourism products and that the intrin- sic value is meaningful to a specific user group, in this case, the African-American expatriate community. This user group, regardless of their social distance from segments of the host community, consider themselves vanguards of collective slave memory. Their sense of belonging to the places of their forebears is fundamental to construct- ing and legitimizing collective identity to the extent of privileging and universalizing their viewpoint at their expense of other social groups and stakeholders. Thus, the Ghanaian destination managers need to make a decision to either shape the presentation of slavery-related sites differently based on the core benefits sought and personal con- nection to slavery or target visitors whose needs and expectations are compatible with the host community. If the African-Americans

had not made the personal commitment to 'return', the options available to site managers would not have been so dire. 


\section{REFERENCES}

Akurang-Parry K. (2010). Ending the Slavery Blame-Game by Henry L. Gates Jr.: Some Perspectives. Retrieved from http://www.ghanaweb. com/GhanaHomePage/features/artikel.php?ID=180999. (Accessed March 30, 2011).

Akyeampong, E. (2000). Africans in the Diaspora: The Diaspora and Africa. Africa Affairs, 99(395), 183-215.

Alderman, D. H. (2010). Surrogation and the Politics of Remembering Slavery in Savannah, Georgia (USA). Journal of Historical Geography, 36(1), 90-101.

Alderman, D. H., Butler, D. L., \& Hanna, S. P. (2016). Memory, Slavery and Plantation Museums: The River Road Project. Journal of Heritage Tourism, 11(3),209-218.

Alderman, D. H., \& Campbell, R. M. (2008). Symbolic Excavation and the Artifact Politics of Remembering Slavery in the American South: Observations from Walterboro, South Carolina. Southeastern Geographer, 48(3), 338-355.

Asiedu, A. (2005). Some Benefits of Migrants' Return Visits to Ghana. Population, Space and Place, 11(1), 1-11.

Austin, N. K. (2002). Managing heritage attractions: Marketing challenges at sensitive historical sites. International Journal of Tourism Research, 4(6), 447-457.

Assensoh, Y. M. A. (2010). African-Americans, African Immigrants and Homeland-Diaspora Development in Africa. African Diaspora, 3(2), 207-234.

Boadi-Siaw, S. (2009). The Afro-Brazilian Expatriates in Ghana. In K. K. Prah (Ed.), Back to Africa Vol. 1: Afro-Brazilian Expatriates and their Communities. (pp. 149-153). Cape Town: CASAS Books.

Bogardus, E. S. (1933). A Social Distance Scale. Sociology and Social Research, 17, 265-271.

Bruner, E. M. (1996). Tourism in Ghana: The Representation of Slavery and the Return of the Black Diaspora. American Anthropologist, 98(2), 290-304.

Butler, D. L., Carter, P. L., \& Dwyer, O. J. (2008). Imagining Plantations: Slavery, Dominant Narratives, and the Foreign Born. Southeastern Geographer, 48(3), 288-302.

Buzinde, C. (2007). Representational Politics of Plantation Heritage Tourism: The Contemporary Plantation as a Social Imaginary. In C. McCarthy, A. Durham, L. Engel, M. Giardina, A. Filmer, \& M. Malagreca (Eds.), Globalizing Cultural Studies: Ethnographic Interventions in Theory, Method, and Policy. (pp. 229-251). New York: Peter Lang.

Carter, P. L. (2015). Virtual Ethnography: Placing Emotional Geographies via YouTube. In S. P. Hanna, A. E. Porter, A. E. Modlin, P. Carter, \& D. L. Butler (Eds.), Social Memory and Heritage Tourism Methodologies. (pp. 48-67). London: Routledge.

Daaku, K. Y. (1970). Trade and Politics on the Gold Coast 1600-1720: A Study of the African Reaction to European Trade. London: Oxford University Press.

Dann, G., \& Seaton, A. (2001). Slavery, Contested Heritage and Thanatourism. Binghamton, NY: Haworth Hospitality Press.

Drachler, J. (1975). Black Homeland, Black Diaspora: Cross-Current of the African Relationship. PortWashington, NY: Kennikat Press.

Drake, S. C. (1966). Negro Americans and the Africa Interest. In J. Davis (Ed.), The American Negro Reference Book. (pp. 662-705). Englewood Cliffs, NJ: Prentice-Hall.

DuBois, W. E. B. (1933). Pan-Africa and the New Racial Philosophy. Crisis, 40, 247.

Dunbar, E. (1968). Black Expatriates. New York: Dutton.
Duval, D. T. (2002). The Return Visit-Return Migration Connection. In C. M. Hall, \& A. Williams (Eds.), Tourism and Migration: New Relationships between Production and Consumption. (pp. 257-276). Dordrecht: Kluwer.

Ebron, P. (2000). Tourist as Pilgrims: Commercial Fashioning of Transatlantic Politics. American Ethnologist, 26(4), 910-932. 
Eichstedt, J., \& Small, S. (2002). Representations of Slavery: Race and Ideology in Southern Plantation Museums. Washington, DC: Smithsonian Institu- tion Press.

Essien, K. (2014). "Afie ni Afie" (Home is Home): Revisiting Reverse Trans- Atlantic Journeys to Ghana and the Paradox of Return. ìrìnkèrindò, 7, 47-75.

Gaines, K. (1999). African-American Expatriates in Ghana and the Black Radical Traditions. Souls, 1, 64-71.

Gallois, C., Callan, V. J., \& Parslow, L. A. (1982). Evaluations of Four Ethnic Groups: Level of Ethnocentrism, Favourability, and Social Distance. Australian Journal of Psychology, 34(3), 369-374.

Gates HL (2010). Ending the Slavery Blame-Game. New York Times, p. A27.

Goodrich, J. N. (1985). Black American Tourists: Some Research Findings. Journal of Travel Research, 249(2), 27-28.

Hanna, S. P. (2008). A Slavery Museum? Race, Memory, and Landscape in Fredericksburg, Virginia. Southeastern Geographer, 48(3), 316-337.

Harris, J. E. (1982). Global dimensions of the African Diaspora. Washington, DC: Howard UniversityPress.

Heckathorn, D. D. (1997). Respondent-driven sampling: A new approach to the study of hidden populations. Social Problems, 44(2), 174-199.

Holsey, B. (2008). Routes of Remembrance: Refashioning the Slave Trade in Ghana. Chicago: University of Chicago Press.

Isaacs, H. R. (1959). The American Negro and Africa: Some Notes. Phylon, 20(3), 219-233.

Karakayali, N. (2009). Social Distance and Affective Orientations. Sociolog- ical Forum, 24(3), 538-562.

Kreamer, C. M. (2004). The Politics of Memory: Ghana's Cape Coast Castle Museum Exhibition "Crossroads of People, Crossroads of Trade". Ghana Studies, 7, 79-91.

Lake, O. (1995). Towards a Pan-African Identity: Diaspora African Repatri- ation in Ghana. Anthropological Quarterly, 68(1), 21-36.

Leite, N. (2005). Travels to an Ancestral Past: On Diasporic Tourism Embodied Memory and Identity. Anthropologica, 9, 273-302.

Levine, D. N. (1979). Simmel at a Distance: On the History and Systematics of the Sociology of the Stranger. In W. A. Shack, \& E. P. Skinner (Eds.), Strangers in African Societies. (pp. 21-36). Berkeley: University of California Press.

Lincoln, Y., \& Guba, E. (1985). Naturalistic Inquiry. Beverly Hills: Sage. Locksley, E. (1986). Black America as a Mobilizing Diaspora: Some

Interna-

tional Implications. In G. Sheffer (Ed.), Modern Diasporas in

International Politics. (pp. 164-211). London: Croom Helm.

Macgonagle, E. (2006). From Dungeons to Dance Parties: Contested Histo- ries of Ghana's Slave Forts. Journal of Contemporary African Studies, 24(2), 249-260.

McCracken, G. (1988). The Long Interview. Newbury Park, CA: Sage.

Mensah, I. (2015). The Roots Tourism Experience of Diaspora Africans: A Focus on the Cape Coast and Elmina Castles. Journal of Heritage Tourism, 10(3), 213-232.

Modlin, E. A. (2008). Tales Told on the Tour: Mythic Representations of Slavery by Docents at North Carolina Plantation Museums. Southeast- ern Geographer, 48(3), 265-287.

Modlin, E. A. (2011). Representing Slavery at Plantation-House Museums in the U.S. South: A Dynamic Spatial Process. Historical Geography, 39, 147-173.

Montes, J., \& Butler, D. L. (2008). Debating Race through the Tourist Plan- tation: Analyzing a New York Times Conversation.
Southeastern Geographer, 48(3), 303-315.

Moore, R. B. (1963). Africa Conscious Harlem. Freedomways, 3, 315-334.

Mowatt, R. A., \& Chancellor, C. H. (2011). Visiting Death and Life: Dark Tourism and Slave Castles. Annals of Tourism Research, 38(4), 1410-1434.

Mwakikagile, G. (2005). Relations between Africans and African-Americans: Misconceptions, Myths and Realities. Johannesburg: Continental Press. 
Nti, K. (2014). "Uniting the African Family": Monuments, Tourism, Development, and Neoliberalism in Ghana-Historic African Diaspora Relations. Journal of Third World Studies, 31(2), 113-125.

Nyaupane, G., Timothy, D. J., \& Poudel, S. (2015). Understanding Tourists in Religious Destinations: A Social Distance Perspective. Tourism Management, 48, 343-353.

Osei-Tutu, B. (2004). African-American Reactions to the Restoration of Ghana's 'Slave Castles'. Public Archaeology, 3, 195-204.

Osei-Tutu, B. (2007). Transformations and Disjunctures in the Homeland: African-American Experiences in Ghana. In J. K. Anquandah, N. J. Opoku-Agyemang, \& M. R. Doortmont(Eds.), Transatlantic Slave Trade: Landmarks, Legacies, Expectations. (pp. 326-342). Accra: Sub-Saharan Publications.

Park, R. E. (1924). The Concept of Social Distance Applied to the Study of Racial Attitudes and Racial Relations. Journal of Applied Sociology, 8 , 339-344.

Potter, A. E. (2016). "She Goes into Character as the Lady of the House": Tour Guides, Performance, and the Southern Plantation. Journal of Heritage Tourism, 11(3), 250-261.

Reed, A. (2004). Sankofa Site: Cape Coast Castle and its Museum as Markers of Memory. Museum Anthropology, 27, 13-23.

Reed, A. (2006). Gateway to Africa: The Pilgrimage Tourism of Diaspora Africans to Ghana. Doctoral Dissertation: Department of Anthropology, Indiana University, Bloomington.

Schramm, K. (2004). Coming Home to the Motherland: Pilgrimage Tourism in Ghana. In J. Eade, \& S. Coleman (Eds.), Reframing Pilgrimage: Cultures in Motion. (pp. 133-149). London: Routledge.

Schuetz, A. (1944). The Stranger: An Essay in Social Psychology. American Journal of Sociology, 49, 499-507.

Shackley, M. (2001). Managing Sacred Sites: Service Provision and Visitor Experience. Continuum: London and New York.

Shepperson, G. (1960). Notes on Negro American Influences on the Emergence of African-American Nationalism. The Journal of African History, 1(2), 299-312.

Shepperson, G. (1966). The African Abroad, or the African Diaspora. Africa Forum, 1(2), 76-93.

Shepperson, G. (1974). The Afro-American Contribution to African Studies. Journal of American Studies, 8(3), 281-301.

Simmel, G. (1971). The stranger. InD. N. Levine(Ed.), Georg Simmelon Individuality and Social Forms. (pp. 143-186). Chicago: University of Chicago Press.

Skinner, E. P. (1963). Strangers in West African Societies. Africa, 33(4), 307-320.
Skinner, E. P. (1982). The Dialectic between Diasporas and Homelands. InJ. E. Harris (Ed.), Global Dimensions of the African Diaspora. (pp. 17-45). Washington, DC: Howard UniversityPress.

Small, S. (2013). Still Back of the Big House: Slave Cabins and Slaveryin Southern Heritage Tourism. Tourism Geographies, 15(3), 405-423.

Strauss, A., \& Corbin, J. (1998). Basics of Qualitative Research. Newbury Park: Sage.

Stuckey, S. (1994). Going through the Storm: The Influence of African-American Art in History. New York: Oxford University Press.

Timothy, D. J. (1997). Tourism and the Personal Heritage Experience. Annals of Tourism Research, 34(3), 751-754.

Timothy, D. J. (2008). Genealogical Mobility: Tourism and the Search for a Personal Past. In D. J. Timothy, \& J. Kay Guelke (Eds.), Geography and Genealogy: Locating Personal Pasts. (pp. 115-135). Aldershot: Ashgate.

Timothy, D. J., \& Teye, V. B. (2004). American Children of the African Diaspora: Journeys to the Motherland. In T. Coles, \& D. J. Timothy (Eds.), Tourism, Diasporas and Space. (pp. 111-123). London: Routledge.

Tölölyan, K. (1996). Rethinking Diaspora(s): Stateless Powerin the Transnational Moment. Diaspora, 5(1), 3-36.

Udom, E. U. E. (1962). The Relationship of Afro-Americans to African Nationalism. Freedomways, 2, 391-407.

Udom, E. U. E. (1971). Black Identity in the International Context. In N. Huggins, M. Kilson, \& D. Fox (Eds.), Key Issues in the Afro-American Experience, Vol 2: since 1865. (pp. 233-258). New York: Harcourt.

Wamba, P. (1999). Kinship - A Family Journey in Africa and America. New York: Penguin Group.

Ward, W. E. F. (1966). A History of Ghana. London: George Allen and Unwin.

Weisbord, R. (1973). Ebony Kinship: Africa, Africans, and the Afro-American. Westport, CT: Greenwood Press.

Wood, M. M. (1934). The Stranger: A Study in Social Relationships. New York: Columbia University Press.

Yankholmes, A., \& McKercher, B. (2015). Rethinking Slavery Heritage Tourism. Journal of Heritage Tourism, 10(3), 233-247.

Zachary, P. (2001). Tangled Roots: For African-Americans in Ghana, the Grass isn't Always Greener. Wall Street Journal.

How to cite this article: Yankholmes A, Timothy DJ. Social distance between local residents and African-American expatriates in the context of Ghana's slavery-based heritage tourism. Int J Tourism Res. 2017. https://doi.org/10.1002/jtr.2121 